\title{
INFLEXIBILITY IN ORGANIZATIONAL DECISION-MAKING
}

\author{
Guillermo CARRASCO ${ }^{1}$, Adrianela ANGELES ${ }^{2}$, \\ Edmundo MARROQUIN-TOVAR ${ }^{3}$
}

\author{
${ }^{1}$ Management and International Business Department, Tecnologico de Monterrey, \\ Calle del puente 222, col. Ejidos de Huipulco, Tlalpan, Mexico \\ ${ }^{2}$ Economics and Business Department, Anahuac University, Av. Universidad Anahuac 46 Col. \\ Lomas Anahuac, C.P. 52786, Huixquilucan, Edo. de Mexico \\ ${ }^{3}$ Economics and Business Department, Universidad Panamericana, \\ Augusto Rodin 498 Col. Insurgentes Mixcoac Del. Benito Juárez, Mexico \\ E-mails: ${ }^{1}$ gcarrasc@itesm.mx; ${ }^{2}$ adrianela.cit@gmail.com (corresponding author); \\ 3emarroq@up.edu.mx
}

Received 28 November 2014; accepted 25 September 2015

\begin{abstract}
The main objective of this investigation is to validate a measurement model that identifies the dimensions of inflexibility in organizational decision-making. For this purpose a Confirmatory Factor Analysis was conducted to assess how well the measured variables represent the constructs, which according to several authors of the literature, have been identified as limitations to organizational decision-making. In this study they were classified in three dimensions: limitations on Strategic Management, limitations on Human Resource Management and limitations on Financial Management.

The analysis is based on data collected from 229 Mexican companies. The results show that the proposed model is a good measure of inflexibility in decision-making of these organizations. In addition, it was identified that the variable that best predicts the limitations in strategic management is the lack of clear objectives. Furthermore, it was found that the strongest predictor of limitations on human resources management is the presence of conflicts between employees; and regarding limitations on financial management, the best predictor is the falling profits of the organization. It is expected that this model will help organizations to identify and eliminate these limitations that constraint the organizational decision-making, facilitating their capability to adapt to the changing environment.
\end{abstract}

Keywords: inflexibility, decision-making, strategic management, human resources management, financial management, measurement model.

JEL Classification: M12, M15.

\section{Introduction}

The management of organizations is a key issue within the business environment, which is moving ever faster, facing increasing globalization of markets, rapid development of new technologies and emergence of new forms of innovation (Sánchez, Heene 1997; Brodsky et al. 2012). To overcome these challenges, an alternative approach to the 
management of these organizations has been proposed, it is focused on the development of flexibility in both, their resources and coordination of their activities in order to respond easier to the changing opportunities (Sánchez, Heene 1997). The work of management is not to create a situation where there are no problems, but to lead the organization towards a balance between flexibility and control of their actions, allowing them to perform the desired changes (Adizes 1989). While strategic flexibility has been widely accepted as a requirement for organizations to achieve success (Kandemir, Acur 2012) and literature on organizational decision-making is extensive (Haropoulou 2013) studies linking both concepts are limited, and there is no consensus regarding how to measure inflexibility in organizational decision-making. Therefore, this research aims to validate the dimensions that underlie this inflexibility based on the revised theory.

\section{Literature review}

\subsection{Organizational flexibility}

The dictionary of the Royal Spanish Academy of Language defines the term flexibility as "the quality of being susceptible to changes or variations according to circumstances or needs." In Table 1, definitions that various authors of literature have elaborated on this concept are provided.

The reviewed authors agree in identifying the organizational flexibility with the ability of adapting to change and, according to Sharfman and Dean (1997) the core of any

Table 1. Definitions of organizational flexibility of several authors of literature

\begin{tabular}{ll}
\hline \multicolumn{1}{c}{ Author (s) } & \multicolumn{1}{c}{ Definition of flexibility } \\
\hline Kickert (1985) & $\begin{array}{l}\text { Management method that is applied in a turbulent and unpredictable } \\
\text { environment. }\end{array}$ \\
\hline Adizes (1989) & It is the function of the entrepreneur's role in decision-making. \\
\hline Evans (1991) & Ability to adjust the means available to achieve the expected future. \\
\hline Volberda (1996) & $\begin{array}{l}\text { The degree to which an organization has a variety of management skills } \\
\text { and rate at which they can be activated to increase the control of the } \\
\text { organization. }\end{array}$ \\
\hline Teece et al. (1997) & $\begin{array}{l}\text { Characteristic of the dynamic capacities of the organization that allows } \\
\text { it to adapt to changes in the environment. }\end{array}$ \\
\hline $\begin{array}{l}\text { Sharfman and Dean } \\
\text { (1997) }\end{array}$ & $\begin{array}{l}\text { The degree to which decision-makers are exploring new ideas and } \\
\text { assumptions about the firm and its strategic context. }\end{array}$ \\
\hline $\begin{array}{l}\text { Wright and Snell } \\
\text { (1998) }\end{array}$ & $\begin{array}{l}\text { The ability of a company to quickly reconfigure resources and activities } \\
\text { in response to environmental demands. }\end{array}$ \\
\hline Kandemir and Acur & $\begin{array}{l}\text { Dynamic capability that enables organizations to make strategic decisions } \\
\text { maintaining multiple simultaneous decision alternatives. }\end{array}$ \\
\hline Bamel et al. (2013) & $\begin{array}{l}\text { The ability to take advantage of pragmatic changes by freely selecting } \\
\text { the most appropriate options. }\end{array}$ \\
\hline
\end{tabular}

Source: own elaboration. 
organizational adaptation is the decision-making process. If this process is rigid or inflexible, is unlikely that the organization can adapt. Mandelbaum (1978) notes that the flexibility of an organization is diminished by factors that limit the ability of change or that create resistance to it. Therefore, a way to increase flexibility is identifying and removing these limitations. Based on the above, the definition of the inflexibility in decision-making proposed in this research is: "disability in organizational management to freely select the most appropriate option to adapt to the changing environment".

\subsection{Decision-making}

Organizational decision-making plays an important role in the flexibility of the organization, because it regulates the availability of monetary, human and physical resources, so that by implementing strategic policy certain objectives can be achieved (Krijnen 1979). Flexibility in decision-making is especially necessary to increase velocity and preferential access to the potential future of the organization, and it is dependant on the available resources and the coordination for the implementation of these in the defined lines of action (Kandemir, Acur 2012). Resources refers to physical, human and financial assets that an organization can employ (Lloréns et al. 2006). Rincón (2012) notes that the organization has three management processes: primary or key, which relate to the purpose of the organization; strategic, which facilitate performance guide to achieve key processes; and supporting processes, that facilitate human and material resources to achieve the key process. Meanwhile, Hillerman (2000) points out that the aspects that define decision-making are the financial resources, human resources, strategies and the organizational structure and every process must have the ability to be flexible to respond to environmental changes. Table 2 presents some of the contributions of various authors who have linked flexibility, organizational decision-making and the perspective from which this connection is addressed.

It can be mentioned that flexibility, as such, being a multidimensional concept both dynamic and abstract (Volberda 1996) has been studied from different angles in its connection with the organizational decision-making. However, it can be identified some similarities between the reviewed authors. For example, both Sharfman and Dean (1997), Kandemir and Acur (2012) approach flexibility in decision-making from a strategic perspective, and Papadakis et al. (1998) examine also strategic decision-making but without linking it to flexibility. As for Adizes (1996) and Bamel et al. (2013) they link the managing flexibility with the organizational process.

Some common factors in the research of these authors may be linked as follows: strategic planning, long-term orientation and innovative climate from Kandemir and Acur (2012) go along with competitive threat and uncertainty from Sharfman and Dean (1997) and with the management style of Adizes (1996), all of them are concepts linked to the strategic management in an organization. The dimensions of teamwork, communication and collaboration in Bamel et al. (2013) relate to both internal commitment from Kandemir and Acur (2012) and staffing and compensations in Adizes (1996); these factors can be linked to the organizational management of human resources. Finally, Adizes (1996) states that the objectives of a flexibly controlled company must target 
Table 2. Contributions of various authors to the inflexibility in organizational decision-making

\begin{tabular}{|c|c|c|}
\hline Author(s) & Perspective & Contribution/Conclusion \\
\hline $\begin{array}{l}\text { Mandelbaum } \\
\text { (1978) }\end{array}$ & $\begin{array}{l}\text { Evaluates flexibility within } \\
\text { the context of the decision } \\
\text { theory. }\end{array}$ & $\begin{array}{l}\text { States that restrictions on system resources, either } \\
\text { in quantity, ability, time or cost, limit the actions } \\
\text { that can be taken to cope with changes and } \\
\text { therefore, affect flexibility. }\end{array}$ \\
\hline Nutt (1993) & $\begin{array}{l}\text { Matches the decision styles } \\
\text { of managers with the } \\
\text { flexibility in the decision- } \\
\text { making. }\end{array}$ & $\begin{array}{l}\text { Remarks that the decision styles "analyzer", } \\
\text { "observer" and "processor data" limit flexibility } \\
\text { in decision-making. The styles "synthesizer" and } \\
\text { "linker" are associated with increased flexibility. }\end{array}$ \\
\hline $\begin{array}{l}\text { Adizes } \\
(1996)\end{array}$ & $\begin{array}{l}\text { Proposes that a controlled } \\
\text { flexibility maintains the } \\
\text { organization in a phase of } \\
\text { fullness in its vital cycle and } \\
\text { this prevents its aging and } \\
\text { death. }\end{array}$ & $\begin{array}{l}\text { States that controlled flexibility is related to a } \\
\text { non-autocratic management style, clear rules and } \\
\text { responsibilities, a strategy that prepares future } \\
\text { businesses and leaders, planning and objectives } \\
\text { addressing cost control, income assurance and the } \\
\text { launch of new products. }\end{array}$ \\
\hline $\begin{array}{l}\text { Sharfman } \\
\text { and } \\
\text { Dean (1997) }\end{array}$ & $\begin{array}{l}\text { Seek to explain the factors } \\
\text { that foster or inhibit flexibility } \\
\text { in the strategic } \\
\text { decision-making. }\end{array}$ & $\begin{array}{l}\text { Describe that less flexibility in decision-making } \\
\text { is linked to more competitive environments. } \\
\text { Organizational resource slack and situations with } \\
\text { high degree of uncertainty favor flexibility in } \\
\text { strategic decision-making. }\end{array}$ \\
\hline $\begin{array}{l}\text { Papadakis } \\
\text { et al. (1998) }\end{array}$ & $\begin{array}{l}\text { Investigate the connection } \\
\text { between strategic decision- } \\
\text { making process and } \\
\text { administrative and contextual } \\
\text { management factors. }\end{array}$ & $\begin{array}{l}\text { State that variables of the internal context (formal } \\
\text { planning, financial performance, corporate } \\
\text { control and size) show more significant effects on } \\
\text { strategic decision-making process than the external } \\
\text { environment variables (heterogeneity, dynamism } \\
\text { and hostility). }\end{array}$ \\
\hline $\begin{array}{l}\text { Kandemir } \\
\text { and } \\
\text { Acur (2012) }\end{array}$ & $\begin{array}{l}\text { Propose a model that } \\
\text { integrates the necessary } \\
\text { resources to create flexibility } \\
\text { in proactive strategic } \\
\text { decision-making. }\end{array}$ & $\begin{array}{l}\text { Show that strategic planning, innovative climate } \\
\text { and internal commitment affect the proactive } \\
\text { strategic decision-making positively. }\end{array}$ \\
\hline $\begin{array}{l}\text { Bamel et al. } \\
\text { (2013) }\end{array}$ & $\begin{array}{l}\text { Examine the connection } \\
\text { between the dimensions of the } \\
\text { organizational process and the } \\
\text { management flexibility. }\end{array}$ & $\begin{array}{l}\text { State that flexibility in organizational management } \\
\text { can be increased through teamwork, open } \\
\text { communication and collaborative decision- making. }\end{array}$ \\
\hline
\end{tabular}

Source: own elaboration.

cost control and income assurance. Along with Mandelbaum's approach (1978) which links resource restrictions to inflexibility, and Papadakis et al. (1998) that highlight the financial dimension in the process of strategic decision-making, financial management is identified as another factor of inflexibility in decision-making.

In addition to the organizational factors mentioned above, the literature presents two other dimensions that influence the decision-making process: environmental and individual level factors (Campos et al. 2015; Sharfman, Dean 1997; Rajagopalan et al. 1993). Environmental factors relates to the impact of social, economic, technological, 
market and competition forces on the organization (Ibrahim et al. 2015). Some authors have examined the decision-making process linked with the external business environment in a specific industry, for example: family firms (Ibrahim et al. 2015); automotive, aviation and e-commerce firms (Campos et al. 2015); biotechnology, hospital and textile companies (Judge, Miller 1991). All these studies have emphasized the strategic aspects of the decision-making in a particular business sector.

In this research, we aim to examine and measure the factors affecting inflexibility in decision-making for organizations situated within the same geographical area, Mexico City. We disregard the external industry's environment. Papadakis et al. (1998) report no environmental influence on the decision-making process; this finding is more important for Latin-European managers, who focus on the internal environment because they tend to perceive a limited control over the external environment (Schneider, De Meyer 1991). Consequently, our discussion focuses on internal rather than external factors.

The individual factors affecting the decision-making process are personal values, cognitive style, personality traits, and personal experience (Campos et al. 2015). The analysis of the impact of this dimension is beyond the scope of this research because each person can manage different levels of complexity according to his or her cognitive schemas and attitudinal aspects (Papadakis et al. 1998; Russo, Schoemaker 1989). Meanwhile, Fredrickson (1986) states that some small organizations are able to succeed in a rapidly changing industry despite the decision-maker's cognitive limitations, when a combination of internal factors is presented, like the presence of a dominant decision-maker pursuing positive goals, with a detailed knowledge of the entire organization.

In accord with the principle of parsimony, we look to narrow our dimension selection by choosing those constructs that the literature review suggested would best represent the internal organizational dimension. According to Papadakis et al. (1998), variables of the internal dimension like formal planning, financial performance, corporate control and size, have shown a more significant impact on decision-making process than contextual or individual management characteristics. Therefore, in this investigation, inflexibility in decision-making will be primarily linked to the limitations on strategic management, human resource management, and financial management.

\subsection{Strategic management}

Strategic management is associated with flexibility because of the high capacity of strategic thinking that is required of management to provide a rapid response to changes (Volberda 1996). The formal process of strategic management usually begins with the CEO and top management team, but in order to be effective, it must immediately reach the rest of the organization (Jara 2005). The main task of strategic management is to define the purpose of the organization (Adizes 1989) which is an ambitious long-term goal built on existing skills and involving all the levels of the organization (Schilling 2008).

In addition to defining this purpose, other tasks of strategic management imply setting economic and social objectives, making policies and screening new product ideas and market opportunities (Schilling 2008). According to Kandemir and Acur (2012) it is expected that organizations with flexibility in their decision-making processes will be 
able to bring new products to the market in a timely manner while still achieving a good quality and satisfactory development costs. The complexity of aligning all these objectives, coupled with the dependence on a single person in the organization, may increase coordination problems (Harrigan, Newman 1990), and the results may reduce the flexibility of the organization (Denrell 2003). Nevertheless, it is common to find an autocratic style of strategic management, especially in young companies (Adizes 1989). For example, in the research performed by Marroquín (2013), where the management style is linked to the stage of the life cycle, his results show that $71 \%$ of surveyed companies are in the early stages of the organizational life cycle, with a strong focus on decision-making by the founder, chairman or managing director. This can become a pathological problem if the founder dominates the organization excessively, and its success depends solely on him (Adizes 1989).

This said, a number of constraints of strategic management have been identified, such as the lack of definition of objectives, the autocratic style of leadership and a lack of planning in marketing strategies.

\subsection{Human resource management}

If the organization was founded or is directed by several people, there may be different management styles and conflict may arise. Adizes (1989) points out that the organization can only succeed if the parties work with mutual respect, otherwise it will be difficult to reach a balance between flexibility and control. Communication processes and relationships between people who carry out the same activity play an important role in the flexibility of the organizations (Krijnen 1979; Volberda 1996). These processes usually affect the human resource management of companies. Stern and Stalk (2002) point out that these relations may include: 1) the connection between the director or manager and his immediate subordinates, 2) the connection between the components of senior management and 3) the connection between management groups and support staff. If diversity of perspectives is reduced by the organization, the possibility of conflict is reduced as well and the coordination of activities is facilitated (Wright, Snell 1998). The internal commitment of groups of individuals allows the progress of projects that make an impact on the flexibility of decision-making (Kandemir, Acur 2012).

This said, it is highlighted that the existence of an atmosphere of conflict in the organization between employees, between managers or between employees and managers limits the human resource management.

\subsection{Financial management}

The financial perspective has historically been a critical indicator of an organization's performance (Rincón 2012). Korsgaard et al. (1995) note that the effectiveness in decision-making depends partly on the cooperation of the financial management in the provision of information and linkage to financial indicators to support the organization's strategy. Papadakis et al. (1998) report that in adverse environments, management can try to explain and interpret the situation in terms of financial analysis and identify the financial reports as an aspect of strategic decision-making. 
Financial management is responsible, amongst other things, for promptly handling problems related to financial sustainability, the ability to function on a level where revenues are greater than expenses (Reissenweber 2012) and with cash shortage. This is a common problem especially in growing businesses (Adizes 1989) because this cash flow is the main source of funding for projects that represent the future of the company (Stern, Stalk 2002). Meanwhile Mandelbaum (1978) mentions that a source of resistance to change is the cost of change, and flexibility can be improved by reducing the cost, Adizes (1996) emphasizes the fact that a company without a system of cost control may appear to be doing well if sales are increasing but the data of past due or deferred costs can be hiding the losses. So controlling costs and ensuring profits should be the objective of companies that seek controlled flexibility. If the organization does have the capacity to mobilize its financial resources in order to carry out preventive actions or respond to future contingencies at an opportune time, it is said then that it has achieved financial flexibility (Byoun 2011).

As such, the constraints in financial management involve the lack of cash, the decrease in profits and the lack of cost controls. As a result, the following hypothesis for this study is stated:

H1: Inflexibility in organizational decision-making can be measured through limitations on strategic management, limitations on human resource management and limitations on financial management.

In Figure 1 the illustrated model represents the connections that pretend to be explained.

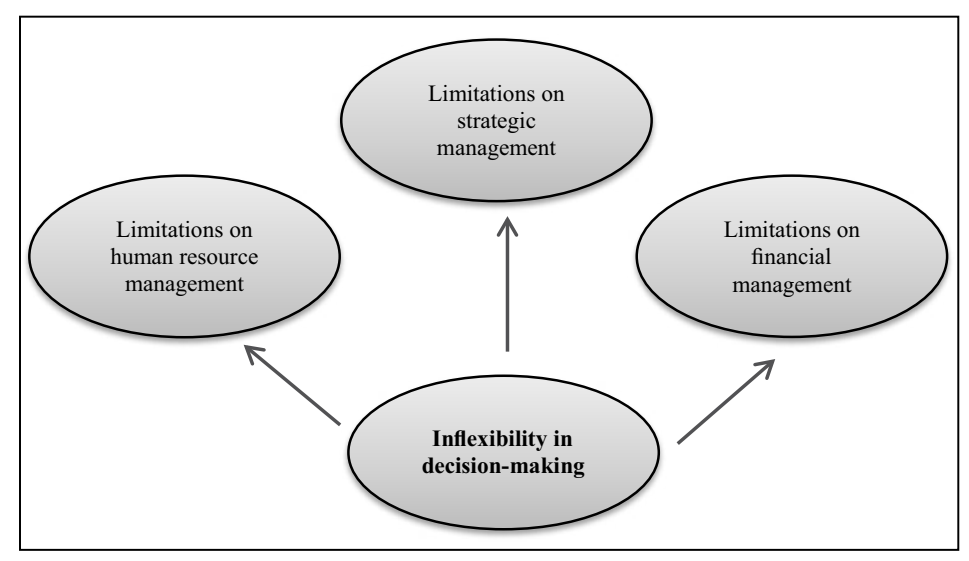

Fig. 1. Inflexibility model in organizational decision-making associated with its limitations on strategic management, human resource management and financial management 


\section{Methodology}

\subsection{Measures}

This study was conducted using mail surveys. The questionnaire used was adapted from the "Adizes Lifecycle Assessment Survey", available on the Adizes ${ }^{\circledR}$ website ${ }^{1}$ from where it was identified and selected a potencial set of items for the constructs under consideration, moreover it was adapted for statistical treatment. Limitations on strategic management were measured via three indicators: leadership style, definition of objectives and planning for the launch of new products. For the human resources factor, the questions were directed to measure the relationship amongst managers, amongst staff and between managers and staff. For the financial factor, the perception on cash, profit performance and cost control was evaluated through subjective measurements, according with Nybakk (2012) this is a common way to measure financial performance and previous studies have shown strong links between objective and subjective measurements of financial performance (Dess, Robinson 1984). Each of the constructs was measured using three to four items, and were operationalized using a 5-point Likert-type scale ranging from $1=$ strongly agree to $5=$ strongly disagree.

\subsection{Data collection}

The survey was mailed to a sample of companies drawn from the Mexican Business Information System (SIEM) and from the Board of National Statistical Economic Units (DENUE) of the National Institute of Statistics and Geography (INEGI), a database of companies active in commerce, industry and services from Mexico City was selected, excluding government institutions and companies that have not registered their profile. The number of usable questionnaires was 229 .

\subsection{Data analysis}

In this study, the sample data were first analyzed with Exploratory Factor Analysis (EFA) using the Statistical Package for Social Sciences (SPSS.21). Factors derived from EFA were then validated by a Confirmatory Factor Analysis (CFA) using the maximum likelihood estimation procedure in EQS.6 for Windows. Regarding the sample size question, in order to run an EFA and CFA, as a general rule, "the minimum is to have at least five times as many observations as the number of variables to be analyzed, and the more acceptable sample size would have a 10:1 ratio" (Hair et al. 2010: 102). To run a CFA, the good practice dictates "a minimum of three items per factor, preferably four" (Hair et al. 2010: 676).

Related literature reports several studies with the same purpose of this research that used a similar sample size, e.g. Lai et al. (2015) performed an EFA and a CFA to verify and confirm a proposed model, and they presented the results of an empirical test conducted among 190 Taiwan manufacturers companies; meanwhile, Lloria and Moreno-Luzon (2014) carried out an EFA and a CFA with a sample of 167 Spanish companies in order to test and validate their proposed measurement scale.

\footnotetext{
${ }^{1}$ http://mexico.adizes.com
} 
In this research, in order to run the EFA, we analyzed eleven variables with 229 observations. For the CFA, we identified three constructs, two of them with four items and another one with three. Therefore, according to the literature, the sample size is sufficient to operate these types of multivariate data analysis.

To assess the measurement model, the data analysis contemplated three indices of absolute goodness of fit: 1) the Root Mean Square Error of Approximation (RMSEA), 2) Joreskog's goodness of fit index (GFI) and 3) Joreskog's adjusted goodness of fit index (AGFI). Also, four comparative fit indexes were considered, contrasting a hypothesized model with a model of independence. These indexes were: 1) Bentler-Bonett's Normed Fit Index (NFI), 2) Bentler-Bonett's non-normed fit index (NNFI), 3) Bentler's Comparative Fit Index (CFI) and 4) Bollen's Incremental Fit Index (IFI).

\section{Results}

The results showed that $20 \%$ of the analyzed companies are manufacturing industries, $15 \%$ are commerce companies and the remaining $65 \%$ are engaged in service activities. These firms were also classified by employed personnel. The following table shows the distribution according to this classification, where it can be noted that more than a half of the surveyed companies were small and medium enterprises (SME's):

Table 3. Distribution of companies by employed personnel (range)

\begin{tabular}{ccccc}
\hline Less than 50 & Between 51 and 100 & Between 101 and 250 & Over 250 & Total \\
\hline 72 & 67 & 45 & 45 & 229 \\
\hline $31.4 \%$ & $29.3 \%$ & $19.7 \%$ & $19.7 \%$ & $100 \%$ \\
\hline
\end{tabular}

The proposed model shows a good fit to the data, in both comparative fit index and absolute fit index, and although the p-value of the $\chi^{2}$ is very low, all other measurements of goodness of fit for the model were satisfactory (Bentler 1990; Browne, Cudeck 1992). Table 4 shows the results of these tests.

Table 4. Goodness of fit of the model Inflexibility in decision-making

\begin{tabular}{ll}
\hline Root Mean Square Error of Approximation (RMSEA) & 0.065 \\
\hline Joreskog's Goodness of Fit Index (GFI) & 0.944 \\
\hline Joreskog's Adjusted Goodness of Fit Index (AGFI) & 0.910 \\
\hline Bentler- Bonett's Normed Fit Index (NFI) & 0.915 \\
\hline Bentler-Bonett's Non-Normed Fit Index (NNFI) & 0.941 \\
\hline Bentler's Comparative Fit Index (CFI) & 0.956 \\
\hline Bollen's Incremental Fit Index or $\varnothing$ Bollen (IFI). & 0.956 \\
\hline Chi-square $=80,628$ Degrees of Freedom $=41$ pvalue $=.0002$ \\
\hline
\end{tabular}




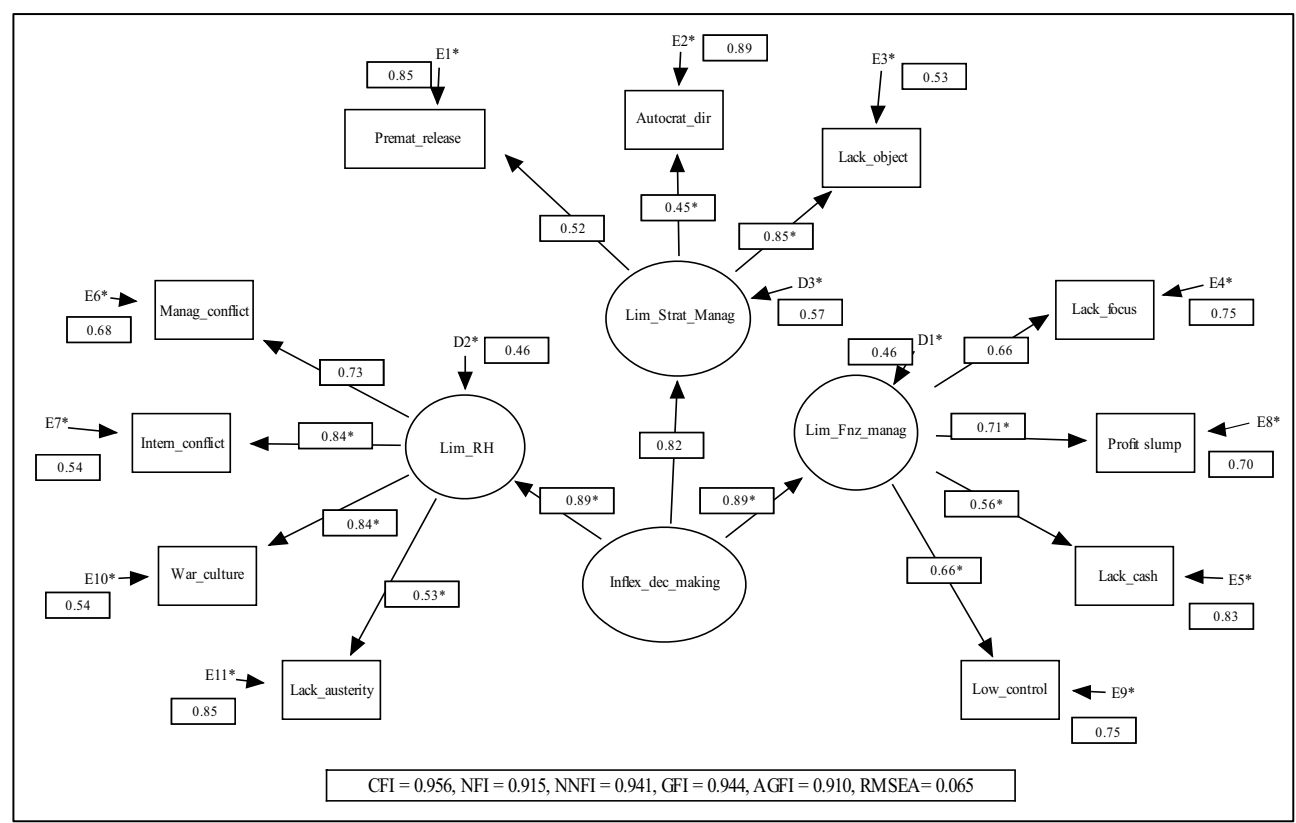

Fig. 2. Measurement model of inflexibility in organizational decision-making

The results for the measurement model are presented in Figure 2 that illustrates the standardized solution, where connections are established based on the coefficients of correlation for the latent variables and on the errors for observable variables.

In the analysis of the variables, the level of statistical significance was set at 0.05 , all connections were significant at this level, thereby indicating that the equations that define the model are a good representation of the information. In Table 5, the factor

Table 5. Measurements of equations with standardized solution

(Statistical significance at 5\% level is marked with @)

\begin{tabular}{lccc}
\hline & & Standardized coefficients & Significance at 5\% \\
\hline Premat_release & V1 & 0.523 F3 + 0.853 E1 & $@$ \\
\hline Autocrat_dir. & V2 & 0.452 F3 + 0.892 E2 & $@$ \\
\hline Lack_object. & V3 & 0.846 F3 + 0.533 E3 & $@$ \\
\hline Lack_focus & V4 & 0.656 F1 + 0.755 E4 & $@$ \\
\hline Lack_cash & V5 & 0.562 F1 + 0.827 E5 & $@$ \\
\hline Manag._conflict & V6 & 0.729 F2 + 0.685 E6 & $@$ \\
\hline Intern_conflict & V7 & 0.840 F2 + 0.542 E7 & $@$ \\
\hline Profit_slump & V8 & 0.715 F1 + 0.699 E8 & $@$ \\
\hline
\end{tabular}


End of Table 5

\begin{tabular}{lccc}
\hline \multicolumn{1}{c}{ Variable } & & Standardized coefficients & Significance at 5\% \\
\hline Low_control & V9 & $0.663 \mathrm{~F} 1+0.749 \mathrm{E} 9$ & $@$ \\
\hline War_culture & V10 & $0.844 \mathrm{~F} 2+0.537 \mathrm{E} 10$ & $@$ \\
\hline Lack_austerity & V11 & $0.532 \mathrm{~F} 2+0.847 \mathrm{E} 11$ & $@$ \\
\hline Lim_Fnz_manag. & F1 & 0.889 F4 + 0.457 D1 & $@$ \\
\hline Lim_RRHH. & F2 & $0.890 \mathrm{~F} 4+0.455 \mathrm{D} 2$ & $@$ \\
\hline Lim_Strat_manag. & F3 & $0.823 \mathrm{~F} 4+0.568 \mathrm{D} 3$ & $@$ \\
\hline
\end{tabular}

loadings under the standardized solution are illustrated. Hair et al. (2010) recommend that these loadings should be greater than 0.5; except for the connection of the variable "autocratic management" to the factor "limitations on strategic management" that reaches a standardized coefficient of 0.452 , all the standardized factor loadings were greater than 0.5 . Hence, the model shows convergent validity (Anderson, Gerbing 1988).

Discriminant validity was examined by estimating confidence intervals at $95 \%$ for the correlation between each pair of latent factors, verifying that it did not include the 1.0 value (Anderson, Gerbing 1988). Table 6 shows the results, where none of the intervals cover 1.0, thus indicating that the model has different constructs for the three analyzed factors and it has discriminant validity.

Table 6. Discriminant validity

\begin{tabular}{cc}
\hline Factors & Confidence interval (95\%) \\
\hline F1-F2 & $0.482-0.922$ \\
\hline F1-F3 & $0.280-0.660$ \\
\hline F2-F3 & $0.358-0.802$ \\
\hline
\end{tabular}

\section{Discussion}

The results of this investigation permitted the identification of three dimensions that form inflexibility in organizational decision-making: limitations on strategic management, limitations on human resource management and limitations on financial management. The strategic dimension has been more frequently associated with flexibility in decision-making in literature (Sharfman, Dean 1997; Kandemir, Acur 2012) than have the human resources or financial dimensions. The latter have been analyzed in their connection with the organizational process, and this in turn is the one that has been linked to flexibility (Bamel et al. 2013). In this study, the three above-mentioned dimensions were empirically analyzed in order to propose a measurement model of inflexibility in organizational decision-making. 
The results showed that the variables that explain the limitations on strategic management are: autocratic management, lack of clear objectives in the organization and premature release of products, of which the lack of clear objectives is the variable that best predicts this limitation (correlation coefficient $=0.846$ ). This is consistent with the literature that indicates that the main task of strategic management is to define the purpose of the organization (Adizes 1989). Also among the variables related to the limitations on human resource management are the existence of internal conflicts among staff, conflicts between managers, the perception of a war culture in the organization and the lack of austerity in managers, of which the conflict among staff members and the war culture are the variables that best explain this limitation (correlation coefficient $=0.84$ ). This is consistent with Kandemir and Acur (2012), who mention that the internal commitment of the members of the organization affects the flexibility in proactive strategic decisionmaking, and with Bamel et al. (2013), who establish that the flexibility in organizational management can be increased through open communication among its members. Furthermore, the variables on the perception of lack of cash, profit slump, lack of cost controls and lack of focus on the business were positively related to the limitations on financial management, of which the perception of profit slump better predicts the limitation on this type of management (correlation coefficient $=0.71$ ). This concurs with what Adizes (1996) reported, meaning that the objectives of an organization seeking controlled flexibility must be cost control-oriented and profit assurance-oriented.

The confirmatory factor analysis model validates that the measured variables represent the constructs in the theoretical model, thus confirming hypothesis 1: the inflexibility in organizational decision-making can be measured through limitations on strategic management, limitations on human resource management and limitation on financial management.

\section{Conclusions}

This study provides a valuable reference point for future research on inflexibility in organizational decision-making as it tries to integrate some of the components still scattered in literature and validate a measurement model.

Although several researches have examined how to promote flexibility in decisionmaking process, only few authors have sought to explain the factors that inhibit this flexibility and the theoretical review previously performed shows that nobody has proposed a model that properly measures the structure of the internal factors that limit the flexibility in organizational decision-making.

According to our results, inflexibility in organizational decision-making is influenced not only for strategic management constraints, but also for human resource management and financial management limitations. These results are consistent with previous findings suggesting that the process of decision-making is more influenced by internal or administrative factors than by the external environment (Papadakis et al. 1998; Bamel et al. 2013). In this context, this research aims to build an original and unique model showing the internal dimensions related to this inflexibility. This article contributes to 
the literature with the presented model, since there is no equivalent empirical or theoretical contribution to the subject in the current literature.

Based on the proposed model it can be said that the three analyzed constructs: limitations on strategic management, limitations on human resource management and limitations on financial management, are a good measurement of inflexibility in organizational decision-making. The results are useful for both managers and researchers because validate the dimensions that underlie inflexibility in organizational decision-making that could limit the firm's ability to overcome new challenges.

This research is useful for both managers and researchers because it validates the dimensions that underlie inflexibility in organizational decision-making that could limit the firm's ability to overcome new challenges and at the same time it can serve as a warning signal to identify the moment when the conditions of inflexibility begin to appear in the organization.

\section{Limitations and recommendations for future research}

It is important to highlight that the results of this investigation allow the identification of the dimensions forming inflexibility in organizational decision-making but not infer causality, which is regarded as one of its limitations. Similarly, another possible improvement to this study is related to financial management which was assessed only through subjective measurements, this aspect could be improved in future research by combining it with objective measurements.

Another limitation is that we do not take into account external or individual decision factors that could also influence the inflexibility in decision-making, because the organizations of our sample were very diverse and belonged to different industry environments. Future research could focus on external factors affecting a particular type of industry and could deepen individual managerial aspects, in order to make more precise the proposed model.

The next steps for the practical use of the results of this study will be to identify and relate the causes that generate the restrictions outlined here, in order to provide more elements to make organizational decisions in a flexible way and to allow the firms to respond easier to the changing opportunities. The refinements to the measures suggested here will be important in developing this research stream.

\section{References}

Adizes, I. 1989. Corporate lifecycles: how and why corporations grow and die and what to do about it. Englewood Cliffs, NJ: Prentice Hall, 111-157.

Adizes, I. 1996. The pursuit of prime: maximize your company's success with the Adizes program. Santa Monica, California: Knowledge Exchange, LLC, 121-141.

Anderson, J. C.; Gerbing, D. W. 1988. Structural equation modeling in practice: a review and recommended two-step approach, Psychological Bulletin 103(3): 411-423.

http://dx.doi.org/10.1037/0033-2909.103.3.411 
Bamel, U.; Rangnekar, S.; Rastogi, R.; Kumar, S. 2013. Organizational process as antecedent of managerial flexibility, Global Journal of Flexible Systems Management 14(1): 3-15.

http://dx.doi.org/10.1007/s40171-013-0026-9

Bentler, P. M. 1990. Comparative fit indexes in structural models, Psychological Bulletin 107(2): 238-246. http://dx.doi.org/10.1037/0033-2909.107.2.238

Brodsky, A.; Egge, N.; Wang, X. 2012. Supporting agile organizations with a decision guidance query language, Journal of Management Information Systems 28(4): 39-68.

http://dx.doi.org/10.2753/MIS0742-1222280403

Browne, M.; Cudeck, R. 1992. Alternative ways of assessing model fit, Sociological Methods \& Research 21(2): 230-258. http://dx.doi.org/10.1177/0049124192021002005

Byoun, S. 2011. Financial flexibility and capital structure decision, Working Paper. Baylor University, Waco Texas.

Campos, H. M.; Parellada, F. S.; Valenzuela, F. A. A.; Rubio, A. M. 2015. Strategic decision-making speed in new technology based firms, Revista de administração e inovação 12(2): 130-152.

Denrell, J. 2003. Vicarious learning, undersampling of failure, and the myths of management, Organization Science 14(3): 227-243. http://dx.doi.org/10.1287/orsc.14.2.227.15164

Dess, G.; Robinson, R. Jr. 1984. Measuring organizational performance in the absence of objective measures: the case of the privately-held firm and conglomerate business unit, Strategic Management Journal 5(3): 265-273. http://dx.doi.org/10.1002/smj.4250050306

Evans, J. S. 1991. Strategic flexibility for high technology manoeuvres: a conceptual framework, Journal of Management Studies 28 (1): 69-89.

http://dx.doi.org/10.1111/j.1467-6486.1991.tb00271.x

Fredrickson, J. W. 1986. The strategic decision process and organizational structure, Academy of Management Review 11(2): 280-297. http://dx.doi.org/10.5465/AMR.1986.4283101

Hair, J. F. Jr.; Black, W. C.; Babin, B. J.; Anderson, R. E. 2010. Multivariate data analysis. 7th ed. Upper Saddle River, NJ: Prentice Hall.

Haropoulou, M. 2013. Organizational decision-making and strategic product creation in the context of business sustainability outcomes: theoretical synthesis and empirical findings: Doctoral thesis. Lincoln University, Christchurch, New Zealand.

Harrigan, K. R.; Newman, W. H. 1990. Bases of interorganization co-operation: propensity, power, persistence, Journal of Management Studies 27(4): 417-434.

http://dx.doi.org/10.1111/j.1467-6486.1990.tb00255.x

Hillerman, W. 2000. Toma de decisions [Decision-Making]: Master's thesis. Universidad Francisco Marroquín, Guatemala (in Spanish). http://dx.doi.org/10.1080/02102412.2006.10779584

Ibrahim, B.; Dumas, C.; McGuire, J. 2015. Strategic decision making in small family firms: an empirical investigation, Journal of Small Business Strategy 12(1): 80-90.

Jara, H. 2005. Dirección estratégica y saneamiento de empresas: el caso Petroperú 2001-2005 [Strategic direction and sanitation of companies: the Petroperu Case 2001-2005]: Master's thesis. Universidad Nacional Mayor de San Marcos, Lima Perú (in Spanish).

Judge, W. Q.; Miller, A. 1991. Antecedents and outcomes of decision speed in different environmental context, Academy of Management Journal 34(2): 449-463. http://dx.doi.org/10.2307/256451

Kandemir, D.; Acur, N. 2012. Examining proactive strategic decision-making flexibility in new product development, Journal of Product Innovation Management 29(4): 608-622.

http://dx.doi.org/10.1111/j.1540-5885.2012.00928

Kickert, W. 1985. The magic word flexibility, International Studies of Management \& Organization 14(4): 6-31. http://dx.doi.org/10.1080/00208825.1984.11656394 
Korsgaard, M. A.; Schweiger, D. M.; Sapienza, H. J. 1995. Building commitment, attachment, and trust in strategic decision-making teams: the role of procedural justice, Academy of Management Journal 38(1): 60-84. http://dx.doi.org/10.2307/256728

Krijnen, H. G. 1979. The flexible firm, International Studies of Management \& Organization 14(4): 64-90. http://dx.doi.org/10.1016/0024-6301(79)90074-8

Lai, C. S.; Chan, D. Y. C.; Yang, C. F.; Hsu, W. C. 2015. The value creation scale of supplierdistributor relationship in international markets, Journal of Business \& Industrial Marketing 30(2): 171-181. http://dx.doi.org/10.1108/JBIM-11-2011-0166

Lloréns, F.; Verdú,A.; García, V. 2006. Flexibilidad estratégica en entornos hipercompetitivos: una visión basada en los recursos financieros de la empresa [Strategic flexibility in hypercompetitive environments: financial resources based view], Spanish Journal of Finance and Accounting 35(129): 387-410.

Lloria, M. B.; Moreno-Luzon, M. D. 2014. Organizational learning: proposal of an integrative scale and research instrument, Journal of Business Research 67(5): 692-697.

http://dx.doi.org/10.1016/j.jbusres.2013.11.029

Mandelbaum, M. 1978. Flexibility in decision making, an exploration and unification: Doctoral thesis. University of Toronto, Canada.

Marroquín, E. 2013. Estudio exploratorio sobre el estilo de dirección que predomina en la etapa del ciclo de vida organizacional de las empresas que ofrecen servicios profesionales, científicos $y$ técnicos en México [An exploratory study on management style that dominates the stage of organizational life cycle of companies offering professional, scientific and technical services in Mexico]: Doctoral thesis. EGADE Business School Tecnologico de Monterrey, México (in Spanish).

Nutt, P. C. 1993. Flexible decision styles and the choices of top executives, Journal of Management Studies 30(5): 695-721. http://dx.doi.org/10.1111/j.1467-6486.1993.tb00322.x

Nybakk, E. 2012. Learning orientation, innovativeness and financial performance in traditional manufacturing firms: a higher-order structural equation model, International Journal of Innovation Management 16(5): 1-28. http://dx.doi.org/10.1142/S1363919612003873

Papadakis, V; Lioukas, S.; Chambers, D. 1998. Strategic decision-making processes: the role of management and context, Strategic Management Journal 19(2): 115-147.

http://dx.doi.org/10.1002/(SICI)1097-0266(199802)19:2<115::AID-SMJ941>3.0.CO;2-5

Rajagopalan, N.; Rasheed, A. M.; Datta, D. K. 1993. Strategic decision processes: critical review and future directions, Journal of Management 19(2): 349-384.

http://dx.doi.org/10.1016/0149-2063(93)90057-T

Reissenweber, B. 2012. Financial indicators in strategic decision making: recommended practices for financial officers at small private colleges and universities in the midwestern United States: Doctoral thesis. Nebraska University.

Rincón, R. 2012. Los indicadores de gestión organizacional: una guía para su definición [The indicators of organizational management: a definition guide], Revista Universidad EAFIT 34(111): 43-59.

Russo, J. E.; Schoemaker, P. J. 1989. Decision traps: ten barriers to brilliant decision-making and how to overcome them. New York: Doubleday. Ed. Fireside, 15-63.

Sánchez, R.; Heene, A. 1997. Managing for an uncertain future, International Studies of Management \& Organization 27(2): 21-42. http://dx.doi.org/10.1080/00208825.1997.11656706

Schilling, M. 2008. Dirección estratégica de la innovación tecnológica [Strategic management of technological innovation]. $2^{\text {nd }}$ ed. Madrid: McGraw Hill, 103-123. 
Schneider, S. C.; De Meyer, A. 1991. Interpreting and responding to strategic issues: the impact of national culture, Strategic Management Journal 12(4): 307-320.

http://dx.doi.org/10.1002/smj.4250120406

Sharfman, M.; Dean, J. Jr. 1997. Flexibility in strategic decision making informational and ideological perspectives, Journal of Management Studies 34(2): 191-217.

http://dx.doi.org/ 10.1111/1467-6486.00048

Stern, C. W.; Stalk, G. Jr. 2002. Ideas sobre estrategia [Ideas on strategy]. Bilbao: Deusto Ediciones, 309-312.

Teece, D. J.; Pisano, G.; Shuen, A. 1997. Dynamic capabilities and strategic management, Strategic Management Journal 18(7): 509-533.

http://dx.doi.org/10.1002/(SICI)1097-0266(199708)18:7<509::AID-SMJ882>3.0.CO;2-Z

Volberda, H. W. 1996. Toward the flexible form: how to remain vital in hypercompetitive environments, Organization Science 7(4): 359-374. http://dx.doi.org/10.1287/orsc.7.4.359

Wright, P. M.; Snell, S. A. 1998. Toward a unifying framework for exploring fit and flexibility in strategic human resource management, Academy of Management Review 23(4): 756-772.

http://dx.doi.org/10.5465/AMR.1998.1255637

Guillermo CARRASCO is a Professor of Business Management at Tecnologico de Monterrey in Mexico City. He received his Ph.D. degree from Universidad Nacional Autonoma de Mexico and his master's degree from Universitat Pompeu Fabra in Barcelona, Spain. He has several papers published in national journals in the areas of strategic management, organizational learning, and organizational behaviour.

Adrianela ANGELES is a Professor of Finance and Business Management at Anahuac University in Mexico. She received his Ph.D. degree in Management Sciences from EGADE Business School, Tecnologico de Monterrey. Her primary research interests lie in organizational decision-making and strategic management in SMEs. She has several articles published in these areas.

Edmundo MARROQUIN-TOVAR is a Professor of Management at Universidad Panamericana, campus Mexico. He received his Ph.D. degree in Management Sciences from EGADE Business School, Tecnologico de Monterrey. Professor Marroquin-Tovar was Chair of the Information Systems Department at Universidad Panamericana's Business School. His main research interests include professional competencies and leadership styles in organizations. He has several papers and conference articles in these areas. 